\title{
Mikrolevät lypsylehmien ruokinnassa: 2. Valkuaisen hyväksikäyttö
}

\author{
Marjukka Lamminen, Anni Halmemies-Beauchet-Filleau, Tuomo Kokkonen, Seija Jaakkola ja Aila \\ Vanhatalo \\ Helsingin yliopisto, Maataloustieteiden laitos, PL 28, 00014 Helsingin yliopisto, etunimi.suku- \\ nimi@helsinki.fi
}

\section{TIIVISTELMÄ}

Mikrolevät ovat kiinnostava valkuaisrehuvaihtoehto huomattavan suuren kasvupotentiaalinsa ja suuren valkuaispitoisuutensa (jopa $700 \mathrm{~g} / \mathrm{kg} \mathrm{ka}$ ) vuoksi. Mikrolevien aminohappokoostumus on lähes rypsin ja soijan veroinen levien pienempää histidiinipitoisuutta lukuun ottamatta. Mikrolevistä lypsylehmien rehuna on vain vähän tutkimustietoa. Tässä tutkimuksessa selvitettiin mikrolevien vaikutusta lypsylehmien valkuaisen hyväksikäyttöön perinteisiin valkuaisrehuihin, rypsiin ja soijaan, verrattuna. Osana EAKR:n rahoittamaa Algae Foods-projektia tehtiin kaksi ruokintakoetta. Kokeessa 1 oli 8 ay-lehmää, joiden poikimisesta oli kokeen alkaessa kulunut 186 pv. Koemallina oli toistettu 4x4 latinalainen neliö. Kontrolliruokinnassa lehmät saivat väkirehuna vilja-leikeseosta ilman valkuaislisää. Isonitrogeenisinä vilja-leikkeen valkuaistäydennyksinä olivat joko rypsirouhe, Spirulina platensis leväjauho tai niiden seos vastaten 2,5 kg:n rypsiannosta/pv. Väkirehuannos oli $12 \mathrm{~kg} / \mathrm{pv}$. Kokeessa 2 oli 4 ay-lehmää, joiden poikimisesta oli 112 pv. Koemallina oli 4x4 latinalainen neliö. Isonitrogeenisinä vilja-leikeseoksen valkuaistäydennyksinä olivat soijarouhe, Spirulina platensis, Chlorella vulgaris sekä Chlorella vulgariksen ja Nannochlorpsis gaditanan seos vastaten 1,8 kg:n soija-annosta/pv. Väkirehuannos oli 12,5 kg/pv. Molemmissa kokeissa lehmät saivat nurmisäilörehua vapaasti. Valkuaistäydennys lisäsi typensaantia kokeessa 1 (+92 g/pv), mutta kokeessa 2 käsittelyiden välillä ei ollut eroa typensaannissa. Valkuaistäydennys ei vaikuttanut maidon valkuaispitoisuuteen eikä -tuotokseen (koe 1). Rypsin korvaaminen Spirulinalla heikensi suuntaa-antavasti valkuaistuotosta $(-45,5 \mathrm{~g} / \mathrm{pv}$, koe 1$)$, mutta maidon valkuaispitoisuudessa ei havaittu eroja. Soija- ja mikroleväruokintojen välillä ei ollut eroja maidon valkuaispitoisuudessa eikä -tuotoksessa (koe 2). Kokeessa 1 sekä valkuaistäydennys että rypsin korvaaminen Spirulinalla lisäsivät pötsin ammoniakkipitoisuutta $(+3,17 \mathrm{ja}+0,56 \mathrm{mmol} / \mathrm{l})$, ja typen eritystä virtsaan $(+7,5 \mathrm{ja}$ $+6,3 \%$-yksikköä) sekä vastaavasti vähensivät typen eritystä maitoon $(-4,3$ ja $-1,65 \%$-yksikköä). Kun eri levälajeja verrattiin soijaan ja toisiinsa, rehuvalkuaisen hyväksikäytössä ei havaittu eroja (koe 2). Kummassakaan kokeessa valkuaislähde ei vaikuttanut mikrobivalkuaisen tuotantoon eikä eläinten typpitaseeseen. Molemmissa kokeissa typen hyväksikäyttö maitovalkuaisen synteesiin oli hyvällä tasolla, lähes $30 \%$, kaikilla koeruokinnoilla. Valkuaistäydennys lisäsi lähes kaikkien välttämättömien aminohappojen pitoisuuksia valtimoveressä ja monien näistä osalta myös maitorauhasen aminohappojen otto lisääntyi (koe 1). Spirulinan rypsiä pienempi histidiinipitoisuus heijastui valtimoveripitoisuuteen ja maitorauhasen histidiinin ottoon, jotka pienenivät mikrolevän osuuden lisääntyessä (koe 1). Kokeessa 2 maitorauhasen histidiinin otossa ei havaittu eroja. Näiden tulosten perusteella useimmat Spirulinan valkuaisen hyväksikäyttöä kuvaavat muuttujat olivat hieman rypsiä heikompia. Sen sijaan soijan ja eri mikrolevälajien välillä ei ollut eroa valkuaisen hyväksikäytössä.

\section{ASIASANAT}

Lypsylehmä, mikrolevä, rypsi, soija, maitovalkuainen, valkuaisen hyväksikäyttö 
Mikrolevät lypsylehmien ruokinnassa: 2. Valkuaisen hyväksikäyttö

\section{JOHDANTO}

Valkuaisrehu on kallista ja tuodaan pääosin ulkomailta Suomeen (Kaukovirta-Norja ym. 2015). Valkuaistäydennys lisää tyypillisesti lypsylehmien säilörehun syöntiä ja maitotuotosta (Allen 2000, Huhtanen ym. 2011). Dieetin valkuaispitoisuuden lisääminen heikentää kuitenkin typen hyväksikäyttöä maitovalkuaiseksi ja lisää typen eritystä sontaan ja virtsaan (Olmos Colmonero ja Broderick 2006, Huhtanen 2008). Mikrolevät ovat kiinnostava valkuaisrehuvaihtoehto huomattavan suuren kasvupotentiaalinsa ja suuren valkuaispitoisuutensa (jopa $700 \mathrm{~g} / \mathrm{kg} \mathrm{ka}$ ) vuoksi. Kirjallisuuden mukaan mikrolevälajien aminohappokoostumus on lähes rypsin ja soijan veroinen, pienempää histidiinipitoisuutta lukuun ottamatta (Lamminen 2014, Luke 2015). Histidiini on lypsylehmien maidontuotantoa ensimmäisenä rajoittava aminohappo viljaan ja nurmisäilörehuun pohjautuvassa ruokinnassa (Vanhatalo ym. 1999, Huhtanen ym. 2002). Mikrolevistä lypsylehmien valkuaisrehuna on vain vähän tutkimustietoa. Tässä tutkimuksessa selvitettiin mikrolevien vaikutusta lypsylehmien valkuaisen hyväksikäyttöön perinteisiin valkuaisrehuihin, rypsiin ja soijaan, verrattuna. Hypoteesina oli, että valkuaistäydennys lisää säilörehun syöntiä ja maitotuotosta, mutta heikentää rehuvalkuaisen hyväksikäyttöä maitovalkuaiseksi. Toisena hypoteesina oli, että mikrolevävalkuaisen hyväksikäyttö maidontuotantoon ei ole aivan rypsin ja soijan valkuaisen veroista johtuen levävalkuaisen pienemmästä histidiinipitoisuudesta.

\section{AINEISTOT JA MENETELMÄT}

Viikin opetus- ja tutkimustilan navetassa tehtiin samanaikaisesti kaksi ruokintakoetta kesällä 2014. Kokeiden toteutus on selostettu yksityiskohtaisemmin rinnakkaisjulkaisussa (Halmemies-Beauchet-Filleau ym. 2016). Kokeessa 1 oli 8 ay-lehmää ja koemallina oli toistettu 4x4 latinalainen neliö. Kontrolliruokinnassa lehmät saivat väkirehuna vilja-melassileikeseosta ilman valkuaislisää. Isonitrogeenisinä valkuaistäydennyksinä olivat rypsirouhe, Spirulina platensis-leväjauho tai näiden seos vastaten $2,5 \mathrm{~kg}: \mathrm{n}$ rypsirouheannosta/pv. Kokeessa 2 oli 4 ay-lehmää ja koemallina oli 4x4 latinalainen neliö. Isonitrogeenisinä vilja-melassileikeseoksen valkuaistäydennyksinä olivat soijarouhe, Spirulina platensis, Chlorella vulgaris sekä Chlorella vulgariksen ja Nannochlorpsis gaditanan seos vastaten 1,8 kg:n soijarouheannosta/pv. Kokeissa käytetyt väkirehuannokset olivat $12 \mathrm{~kg} / \mathrm{pv}$ (koe 1) ja 12,5 kg/pv (koe 2) sisältäen kivennäis- ja vitamiinilisän. Molemmissa kokeissa lehmät saivat nurmiheinäsäilörehua vapaasti. Nurmisäilörehu oli korjattu 2. sadosta elokuun alussa 2013 pyöröpaaleihin lyhyen esikuivauksen jälkeen käyttäen muurahaishappopohjaista säilöntäainetta. Lehmät olivat kytkettyinä parsiin, jotka oli varustettu vaa'allisin RIC-rehukupein (Insentec B.V., Marknesse, Alankomaat) ja ne lypsettiin kahdesti päivässä klo 6.00 ja 17.00 .

Koejaksojen kaksi ensimmäistä viikkoa olivat totutusviikkoja ja kolmas viikko keruuviikko. Keruuviikon aikana syötettävistä rehuista (koejakson päivät 15-21), sonnasta (17-20), virtsasta (18-19), maidosta (18-20), pötsinesteestä (20, koe 1) sekä häntä- ja maitosuonen verestä (21) otettiin näytteet. Sonta- ja virtsanäytteet otettiin spot-näytteinä. Säilörehun ja väkirehun syönti sekä maitotuotos kirjattiin ylös päivittäin. Ravintoaineiden sulavuus laskettiin happoon liukenemattoman tuhkan (AIA) avulla. Näytteet analysoitiin ja tulokset laskettiin Ylisen (2015) kuvaamien menetelmien ja kaavojen mukaan. Plasman virtaus maitorauhaseen laskettiin Fickin säännön mukaan perustuen fenyylilalaniinin ja tyrosiinin siirtymiseen plasmasta maitovalkuaiseen. Maitorauhasen aminohappojen otto laskettiin käyttäen kaavaa (pitoisuus valtimoplasmassa - pitoisuus laskimoplasmassa) x plasman virtaus maitorauhaseen. Pötsissä tuotetun mikrobivalkuaisen määrä määritettiin virtsan puriinijohdannaisten avulla (Chen ja Gomes 1992)

Tulosten analysointiin käytettiin SAS-ohjelmiston (versio 9.3, SAS Institute Inc., Cary, Yhdysvallat) Mixed-proseduurin varianssianalyysiä. Kokeen 1 tilastollisessa mallissa kiinteinä muuttujina olivat koeruokinta, neliö ja jakson vaikutus neliössä sekä satunnaismuuttujana eläin neliössä. Kokeen 2 tilastollisessa mallissa kiinteinä muuttujina olivat koeruokinta ja jakso ja satunnaismuuttujana eläin. Kummassakaan kokeessa typen saanti ei ollut normaalijakautunut, minkä vuoksi se analysoitiin neliömuunnoksen jälkeen.

\section{TULOKSET JA TULOSTEN TARKASTELU}

Koerehujen koostumus on esitetty taulukossa 1. Kokeissa käytetty säilörehu oli säilönnälliseltä laadultaan hyvää. Se sisälsi kuitenkin suhteellisen vähän raakavalkuaista (135 g/kg kuiva-ainetta (ka)) ja sen D-arvo oli kohtalainen (656 g/kg ka). Spirulina ja Chlorella sisälsivät runsaasti raakavalkuaista. Nan- 
nochloropsiksen raakavalkuaispitoisuus oli muita mikroleviä pienempi ja sijoittui valkuaispitoisuudeltaan rypsi- ja soijatiivisteiden väliin. Mikrolevien valkuainen sisälsi rypsi- ja soijatiivistettä vähemmän histidiiniä, isoleusiiniä ja tryptofaania, mutta enemmän metioniinia ja fenyylialaniinia. Spirulina ja Chlorella eivät sisältäneet lainkaan neutraalidetergenttikuitua (NDF) ja myös Nannochloropsiksessa sitä oli vähän. Nannochloropsis sisälsi muita mikroleviä enemmän tuhkaa.

Taulukko 1. Koerehujen koostumus

\begin{tabular}{|c|c|c|c|c|c|c|c|c|c|}
\hline & \multirow{2}{*}{$\begin{array}{l}\text { Säilö- } \\
\text { rehu }{ }^{1}\end{array}$} & \multirow{2}{*}{$\begin{array}{c}\text { Vilja- } \\
\text { melassi- } \\
\text { leikeseos }\end{array}$} & \multirow[b]{2}{*}{$\begin{array}{l}\text { Melassi- } \\
\text { leike }\end{array}$} & \multirow[b]{2}{*}{$\begin{array}{l}\text { Seos- } \\
\text { melassi }\end{array}$} & \multirow[b]{2}{*}{$\begin{array}{l}\text { Rypsi- } \\
\text { tiiviste }\end{array}$} & \multirow{2}{*}{$\begin{array}{l}\text { Soija- } \\
\text { tiiviste }\end{array}$} & \multicolumn{3}{|c|}{ Mikrolevät } \\
\hline & & & & & & & Spirulina & Chlorella & $\begin{array}{l}\text { Nanno- } \\
\text { chloropsis }\end{array}$ \\
\hline Kuiva-aine, $\mathrm{g} / \mathrm{kg}$ & 377 & 900 & 879 & 706 & 866 & 878 & 946 & 948 & 962 \\
\hline \multicolumn{10}{|c|}{ Kuiva-aineessa, g/kg } \\
\hline Tuhka & 81,7 & 34,3 & 66,8 & 103 & 66,1 & 75,5 & 71,8 & 51,4 & 158 \\
\hline $\mathrm{NDF}^{2}$ & 496 & 362 & 339 & - & 272 & 145 & 0 & 0 & 76,8 \\
\hline Raakavalkuainen & 135 & 122 & 112 & 13,0 & 311 & 439 & 697 & 586 & 385 \\
\hline \multicolumn{10}{|c|}{ Välttämättömät aminohapot, $\mathrm{g} / \mathrm{kg}$ raakavalkuaista } \\
\hline Arginiini & 39,0 & 57,2 & 39,1 & & 65,9 & 78,6 & 77,0 & 58,0 & 62,0 \\
\hline Fenyylialaniini & 47,9 & 47,4 & 33,9 & & 44,7 & 55,3 & 105 & 99,4 & 99,6 \\
\hline Histidiini & 17,7 & 22,7 & 27,5 & & 28,0 & 27,4 & 16,6 & 18,3 & 17,6 \\
\hline Ilsoleusiini & 39,5 & 34,0 & 36,7 & & 40,9 & 46,1 & 8,11 & 14,0 & 18,6 \\
\hline Leusiini & 73,2 & 66,3 & 57,0 & & 74,2 & 79,9 & 51,9 & 32,6 & 38,9 \\
\hline Lysiini & 49,3 & 34,7 & 52,5 & & 53,3 & 62,5 & 38,8 & 59,5 & 55,2 \\
\hline Metioniini & 11,6 & 10,3 & 9,96 & & 12,9 & 9,76 & 22,2 & 20,8 & 19,4 \\
\hline Treoniini & 42,5 & 36,5 & 40,3 & & 48,8 & 43,1 & 49,3 & 38,8 & 44,8 \\
\hline Tryptofaani & 14,6 & 18,6 & 14,5 & & 21,8 & 20,5 & 4,43 & 5,56 & 5,07 \\
\hline Valiini & 52,1 & 48,3 & 49,6 & & 52,7 & 47,0 & 57,7 & 48,1 & 50,4 \\
\hline Haaraketjuiset $^{3}$ & 165 & 149 & 143 & & 168 & 173 & 118 & 95,0 & 108 \\
\hline Välttämättömät & 387 & 376 & 361 & & 443 & 470 & 431 & 395 & 412 \\
\hline $\begin{array}{l}\text { Ei-välttämättö- } \\
\text { mät }\end{array}$ & 411 & 513 & 375 & & 506 & 532 & 468 & 439 & 464 \\
\hline Yhteensä & 799 & 889 & 736 & & 949 & 1003 & 899 & 834 & 875 \\
\hline
\end{tabular}

${ }^{1}$ Säilörehun käymislaatu (g/kg kuiva-ainetta): maitohappo 27,2, etikkahappo 6,8, propionihappo 0,8 , voihappo 0,2 ja vesiliukoiset hiilihydraatit 136, $\mathrm{pH}$ 4,24, ammoniumtyppi 19,6 g/kg N. D-arvo $656 \mathrm{~g} / \mathrm{kg}$ kuiva-ainetta.

${ }^{2}$ Neutraalidetergenttikuitu

${ }^{3}$ Isoleusiini, Leusiini, Valiini

\section{Koe 1. Valkuaistäydennys sekä rypsirouheen korvaaminen Spirulinalla}

Valkuaistäydennys lisäsi typen saantia, dieetin raakavalkuaispitoisuutta (125 vs. $149 \mathrm{~g}$ raakavalkuaista/kg dieetin ka, $\mathrm{P}<0,001)$ ja lähes kaikkien välttämättömien aminohappojen pitoisuutta plasmassa (taulukko 2). Säilörehun pienestä raakavalkuaispitoisuudesta johtuen kaikkien koeruokintojen raakavalkuaispitoisuudet jäivät suhteellisen pieniksi. Vaikka valkuaistäydennys lisäsi $(\mathrm{P}<0,05)$ plasman histidiinipitoisuutta, sillä ei ollut vaikutusta $(\mathrm{P}>0,10)$ maitorauhasen histidiinin ottoon. Plasman histidiinipitoisuus oli suuri kaikissa koeruokinnoissa (yli $54 \mu \mathrm{mol} / \mathrm{l}$ ) eikä se täten todennäköisesti ollut maidontuotantoa ensimmäisenä rajoittava aminohappo tässä tutkimuksessa. Huolimatta maitorauhasen suuremmasta $(\mathrm{P}<0,05)$ välttämättömien aminohappojen otosta, valkuaislisä ei vaikuttanut $(\mathrm{P}>0,10)$ maidon valkuaispitoisuuteen tai -tuotokseen (keskimäärin 37,2 g/kg ja 1011 g/pv, Halmemies-Beauchet-Filleau ym. 2016).

Valkuaistäydennys heikensi typen hyväksikäyttöä, sillä se lisäsi pötsinesteen ammoniakkipitoisuutta $(\mathrm{P}<0,001)$ ja maidon ureapitoisuutta $(\mathrm{P}<0,001)$ vaikuttamatta valkuaistuotokseen. Tämän seurauksena typpeä jakautui vähemmän maitoon $(-4,3 \%$-yks., $\mathrm{P}<0,001)$ ja sontaan $(-4,1 \%$-yks, $\mathrm{P}<0,001)$ ja enemmän virtsaan $(+7,4 \%$-yks., $\mathrm{P}<0,10)$. Maidon ureapitoisuus oli kuitenkin melko pieni valkuaislisättömällä kontrolliruokinnalla, vain $13,6 \mathrm{mg} / 100 \mathrm{ml}$, joka viittaa pötsimikrobien typenpuutteeseen. Huhtasen (2010) mukaan pötsissä on riittävästi hajoavaa valkuaista pötsimikrobien tarpeisiin, kun maidon ureapitoisuus ylittää $18 \mathrm{mg} / 100 \mathrm{ml}$. Pötsimikrobeilla saattoi olla kontrolliruokinnassa valkuaisen puutteen lisäksi myös energian puute. Huolimatta hyvästä säilönnällisestä laadusta, säilörehu oli kokeen 


\section{Mikrolevät lypsylehmien ruokinnassa: 2 . Valkuaisen hyväksikäyttö}

alussa lähes ylivuotista ja sen D-arvo oli tyydyttävä. Täten säilörehun energia-arvo oli todennäköisesti pieni. Dieetin orgaanisen aineen sekä NDF:n sulavuudet olivat myös alhaisella tasolla koko kokeessa.

Dieetin valkuaispitoisuuden lisääminen heikentää tyypillisesti typen hyväksikäyttöä maitovalkuaiseksi (Olmos Colmonero ja Broderick 2006, Huhtanen ym. 2008). MTT:n aineistossa $10 \mathrm{~g} / \mathrm{kg}$ ka raakavalkuaispitoisuuden lisäys dieetissä on vähentänyt typen hyväksikäyttöä 1,4 \% (Huhtanen ja Shingfield 2005). Muutokset typen jakautumisessa sontaan ja virtsaan kuvastavat typen saannin ja sulavuuden lisääntymistä $(\mathrm{P}<0,001)$ valkuaistäydennyksen myötä. Myös aikaisemmissa kokeissa valkuaistäydennys on tyypillisesti lisännyt typen sulavuutta (Olmos Colmonero ja Broderick 2006, Huhtanen ym. 2011). Muutokset typen jakaantumisessa eivät kuitenkaan pääsääntöisesti olleet kovin suuria ruokintojen välillä, sillä kaikkien koeruokintojen raakavalkuaispitoisuudet olivat korkeintaan $150 \mathrm{~g} / \mathrm{kg} \mathrm{ka}$. Kun ruokinnan raakavalkuaispitoisuus ylittää $150 \mathrm{~g} / \mathrm{kg} \mathrm{ka}$, typen erittyminen virtsaan lisääntyy merkittävästi (Castillo ym. 2000). Todennäköisesti energian saanti rajoitti tässä kokeessa pötsimikrobien valkuaissynteesiä myös valkuaistäydennetyillä ruokinnoilla eivätkä mikrobit täten pystyneet käyttämään lisävalkuaista täysimääräisesti hyväkseen. Huhtasen ym. (2011) mukaan lisääntynyt energian saanti parantaa myös OIV:n hyväksikäyttöä maidontuotantoon. Koska lehmät olivat yli laktaatiokauden keskivälin, on myös mahdollista, että lisävalkuaisen tarve ei enää ollut kovin suuri. Lisävalkuaisella on kuitenkin tyypillisesti saatu positiivinen tuotosvaste myös loppulaktaatiossa (Saarisalo ym. 1997). Kokonaisuudessaan typen hyväksikäyttö maitovalkuaisen synteesiin oli kuitenkin hyvällä tasolla, noin $30 \%$, kaikilla koeruokinnoilla. MTT:n koeaineistossa typen hyväksikäyttö on ollut keskimäärin $28,1 \%$ lypsylehmillä tehdyissä ruokintakokeissa (Nousiainen ym. 2003).

Spirulinan rypsiä pienempi histidiinipitoisuus heijastui plasman histidiinipitoisuuteen ja maitorauhasen histidiinin ottoon, jotka pienenivät suuntaa-antavasti Spirulinan korvatessa rypsiä $(\mathrm{P}<0,10)$. Histidiinin saantia Spirulina-dieeteillä vähensi entisestään väkirehun heikko maittavuus, jolloin säilörehun osuus dieeteissä lisääntyi rypsiruokintaan verrattuna. Plasman histiidiinipitoisuus oli kuitenkin suhteellisen suuri kaikissa koeruokinnoissa. Dieetin mahdollisesti epätasapainoinen aminohappokoostumus vaikutti myös typen hyväksikäyttöön. Pötsin ammoniakkipitoisuus lisääntyi Spirulinan korvatessa rypsiä $(+0,56 \mathrm{mmol} / 1, \mathrm{P}<0,10)$, jolloin typen hyväksikäyttö maidontuotantoon heikkeni $(-1,65 \%$-yks., $\mathrm{P}<0,01)$ ja virtsaan erittyvän typen osuus lisääntyi suuntaa-antavasti $(+6,3 \%$-yks., $\mathrm{P}<0,10)$. Rypsin korvaaminen Spirulinalla heikensi suuntaa-antavasti valkuaistuotosta $(-45,5 \mathrm{~g} / \mathrm{pv}, \mathrm{P}<0,10)$, mutta maidon valkuaispitoisuudessa ei havaittu eroja (Halmemies-Beauchet-Filleau ym. 2016).

\section{Koe 2. Soijarouheen korvaaminen eri mikrolevillä}

Typen hyväksikäytössä ei ollut juuri lainkaan eroja soija- ja mikroleväruokintojen välillä (taulukko 3). Kun osa Chlorellasta korvattiin vähemmän raakavalkuaista sisältävällä Nannochloropsiksella, dieetin raakavalkuaispitoisuus pieneni suuntaa-antavasti $(\mathrm{P}<0,10)$. Tämä johtui Nannochloropsiksen huonommasta maittavuudesta. Koekäsittelyiden välillä ei kuitenkaan ollut eroa $(\mathrm{P}>0,10)$ typen saannissa.

Numeerisesti käsittelyiden väliset erot plasman histidiinipitoisuudessa olivat suuremmat kokeessa 2 kuin kokeessa 1, mutta erot eivät tulleet kokeessa 2 tilastollisesti merkitseviksi suuremman hajonnan vuoksi. Mikrolevien, ja rypsin ja soijan välillä oli yhtä suuri tasoero histidiinipitoisuudessa (taulukko 1), joten erot plasman histidiinipitoisuudessa kokeiden ja mikroleväkäsittelyiden välillä johtuvat todennäköisesti erilaisesta väkirehun syönnistä. Numeerisesti pienin plasman histidiinipitoisuus mitattiin Chlorellaa ja Nannochloropsista sisältäneessä ruokinnassa $(45,5 \mu \mathrm{mol} / \mathrm{l})$. Molemmissa kokeissa plasman histidiinipitoisuudet olivat kuitenkin suhteellisen suuria verrattuna Korhosen (2003) keräämään suomalaiseen aineistoon, jossa plasman histidiinipitoisuus on vaihdellut 17-42 $\mu \mathrm{mol} / 1$ (keskimäärin $23 \mu \mathrm{mol} / 1)$. Nyt tehdyissä kokeissa plasman metioniinin ja lysiinin pitoisuudet vastaavat Korhosen (2003) aineistoa. On siis epätodennäköistä, että mikrolevien histidiinipitoisuus rajoitti tässä kokeessa maidontuotantoa.

Maitotuotos sekä maidon valkuaispitoisuus ja -tuotos pysyivät muuttumattomina kokeessa 2 koekäsittelyistä riippumatta (keskimäärin $30,6 \mathrm{~kg} / \mathrm{pv}, 31,9 \mathrm{~g} / \mathrm{kg}$ ja $980 \mathrm{~g} / \mathrm{pv}$, Halmemies-Beauchet-Filleau ym. 2016). Tällöin ei myöskään havaittu eroja typen jakautumisessa. Typen hyväksikäyttö maitovalkuaisen synteesiin oli tässäkin kokeessa hyvällä tasolla, ollen keskimäärin 30,3 \%, ja virtsaan ja sontaan erittyvän typen osuudet olivat keskimäärin $30,1 \%$ ja $39,7 \%$, vastaavasti. 
SUOMEN MAATALOUSTIETEELLISEN SEURAN JULKAISUJA NO 33

Vaihtoehtoja valkuaistuotantoon

Mikrolevät lypsylehmien ruokinnassa: 2 . Valkuaisen hyväksikäyttö

Taulukko 2. Koe 1: Valkuaisen hyväksikäyttö

\begin{tabular}{|c|c|c|c|c|c|c|c|c|}
\hline & \multicolumn{4}{|c|}{ Koeruokinta } & \multirow[b]{2}{*}{ SEM } & \multicolumn{3}{|c|}{$P$-arvo ${ }^{1}$} \\
\hline & $\begin{array}{l}\text { Kont- } \\
\text { rolli }\end{array}$ & Rypsi & $\begin{array}{c}\text { Rypsi+ } \\
\text { Spirulina }\end{array}$ & Spirulina & & $\begin{array}{c}\text { Valkuais- } \\
\text { lisä }\end{array}$ & $\begin{array}{c}\text { Spirulina } \\
\text { lineaarinen }\end{array}$ & $\begin{array}{r}\text { Spirulina } \\
\text { 2. aste }\end{array}$ \\
\hline \multicolumn{9}{|l|}{$\overline{\text { Syönti, } \mathrm{kg} / \mathrm{pv}}$} \\
\hline Säilörehun kuiva-aine & 12,2 & 12,9 & 12,8 & 13,3 & 0,57 & o & & \\
\hline Dieetin kuiva-aine & 22,8 & 23,4 & 23,0 & 22,8 & 0,49 & & & \\
\hline $\mathrm{N}, \mathrm{g} / \mathrm{pv}^{2}$ & 457 & 546 & 549 & 552 & & $* * *$ & & \\
\hline \multicolumn{9}{|c|}{ Syödyn dieetin koostumus, $\mathrm{g} / \mathrm{kg}$ kuiva-ainetta } \\
\hline Väkirehun osuus dieetissä & 466 & 451 & 449 & 422 & 15,2 & $*$ & $*$ & \\
\hline Raakavalkuainen & 125 & 146 & 149 & 151 & 0,6 & $* * *$ & $* * *$ & \\
\hline Neutraalidetergenttikuitu & 421 & 413 & 409 & 409 & 2,4 & $* * *$ & & \\
\hline \multicolumn{9}{|l|}{ Sulavuus, $g / \mathrm{kg}$} \\
\hline Orgaaninen aine & 646 & 660 & 657 & 661 & 5,5 & $* *$ & & \\
\hline $\mathrm{N}$ & 572 & 609 & 608 & 623 & 8,3 & $* * *$ & & \\
\hline Neutraalidetergenttikuitu & 441 & 481 & 475 & 494 & 11,3 & $* * *$ & & \\
\hline Pötsinesteen $\mathrm{NH}_{3}-\mathrm{N}, \mathrm{mmol} / \mathrm{l}$ & 2,52 & 5,32 & 5,38 & 6,37 & 0,661 & $* * *$ & o & \\
\hline Pötsin mikrobi-N, $g / p v^{3}$ & 224 & 235 & 228 & 229 & 9,2 & & & \\
\hline Maidon urea, $\mathrm{mg} / \mathrm{dl}$ & 13,6 & 20,2 & 22,1 & 20,2 & 0,99 & $* * *$ & & $*$ \\
\hline \multicolumn{9}{|l|}{ Njakaantuminen } \\
\hline $\mathrm{N}$ tase, $\mathrm{g} / \mathrm{pv}^{4}$ & $-7,88$ & 17,1 & $-0,62$ & $-6,49$ & 17,128 & & & \\
\hline $\mathrm{N}$ maidossa, $\mathrm{g} / \mathrm{pv}$ & 157 & 164 & 156 & 157 & 4,9 & & o & \\
\hline $\mathrm{N}$ sonnassa, g/pv & 196 & 214 & 215 & 208 & 6,20 & $* *$ & & \\
\hline $\mathrm{N}$ virtsassa, $\mathrm{g} / \mathrm{pv}$ & 113 & 152 & 178 & 194 & 14,6 & $* *$ & o & \\
\hline $\mathrm{N}$ maidossa, $\%$ & 34,3 & 30,0 & 28,3 & 28,4 & 0,79 & $* * *$ & $* *$ & \\
\hline $\mathrm{N}$ sonnassa, $\%$ & 42,8 & 39,1 & 39,2 & 37,7 & 0,84 & $* * *$ & & \\
\hline $\mathrm{N}$ virtsassa, $\%$ & 24,6 & 27,8 & 32,7 & 35,4 & 3,01 & o & o & \\
\hline \multicolumn{9}{|c|}{ Plasman välttämättömät aminohapot, $\mu \mathrm{mol} / l$} \\
\hline Arginiini & 81,3 & 89,2 & 89,7 & 92,9 & 3,32 & $*$ & & \\
\hline Fenyylialaniini & 51,3 & 55,1 & 54,3 & 54,2 & 2,05 & o & & \\
\hline Histidiini & 54,8 & 65,1 & 64,1 & 58,8 & 3,04 & $*$ & o & \\
\hline Isoleusiini & 136 & 149 & 144 & 150 & 4,55 & $*$ & & \\
\hline Leusiini & 133 & 162 & 156 & 152 & 6,1 & $* *$ & & \\
\hline Lysiini & 106 & 115 & 115 & 117 & 3,7 & $*$ & & \\
\hline Metioniini & 23,0 & 24,9 & 24,1 & 24,7 & 0,82 & & & \\
\hline Treoniini & 103 & 117 & 111 & 118 & 3,5 & $* *$ & & o \\
\hline Tryptofaani & 40,1 & 41,5 & 40,3 & 39,4 & 1,22 & & & \\
\hline Valiini & 264 & 309 & 292 & 292 & 11,6 & $* *$ & & \\
\hline Haaraketjuiset $^{5}$ & 532 & 620 & 591 & 593 & 20,6 & $* *$ & & \\
\hline Välttämättömät & 991 & 1127 & 1090 & 1099 & 28,0 & $* *$ & & \\
\hline Ei-välttämättömät & 1768 & 1752 & 1725 & 1757 & 47,8 & & & \\
\hline Yhteensä & 2759 & 2879 & 2816 & 2856 & 55,1 & o & & \\
\hline \multicolumn{9}{|c|}{ Maitorauhasen välttämättömien aminohappojen otto, mmol/pv } \\
\hline Arginiini & 556 & 624 & 639 & 604 & 37,7 & o & & \\
\hline Fenyylialaniini & 319 & 352 & 339 & 337 & 15,9 & $*$ & & \\
\hline Histidiini & 237 & 250 & 214 & 212 & 12,9 & & o & \\
\hline Isoleusiini & 558 & 772 & 609 & 698 & 68,3 & o & & \\
\hline Leusiini & 836 & 1016 & 961 & 940 & 59,0 & $*$ & & \\
\hline Lysiini & 798 & 868 & 840 & 836 & 40,8 & & & \\
\hline Metioniini & 186 & 214 & 182 & 195 & 12,9 & & & $\mathrm{o}$ \\
\hline Treoniini & 443 & 497 & 312 & 396 & 75,5 & & & \\
\hline Tryptofaani & 30,8 & 40,2 & 3,84 & 19,8 & 21,57 & & & \\
\hline Valiini & 672 & 944 & 867 & 882 & 81,3 & $*$ & & \\
\hline Haaraketjuiset $^{5}$ & 2066 & 2732 & 2437 & 2520 & 184,8 & $*$ & & \\
\hline Välttämättömät & 4635 & 5578 & 4967 & 5120 & 262,8 & $*$ & o & \\
\hline Ei-välttämättömät & 4009 & 3736 & 2791 & 3196 & 526,5 & & & \\
\hline Yhteensä & 8644 & 9314 & 7736 & 8316 & 637,3 & & & \\
\hline
\end{tabular}


SUOMEN MAATALOUSTIETEELLISEN SEURAN JULKAISUJA NO 33

Vaihtoehtoja valkuaistuotantoon

Mikrolevät lypsylehmien ruokinnassa: 2. Valkuaisen hyväksikäyttö

Taulukko 3. Koe 2: Valkuaisen hyväksikäyttö

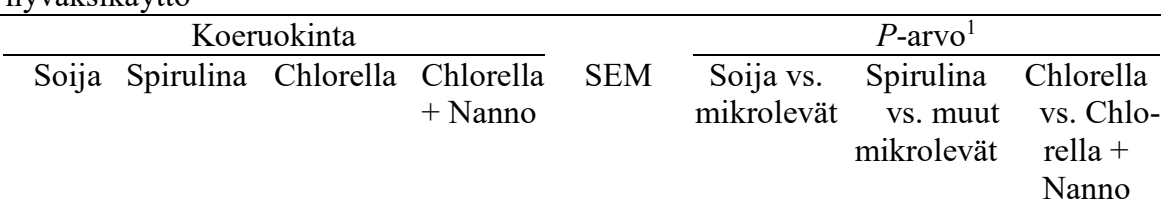

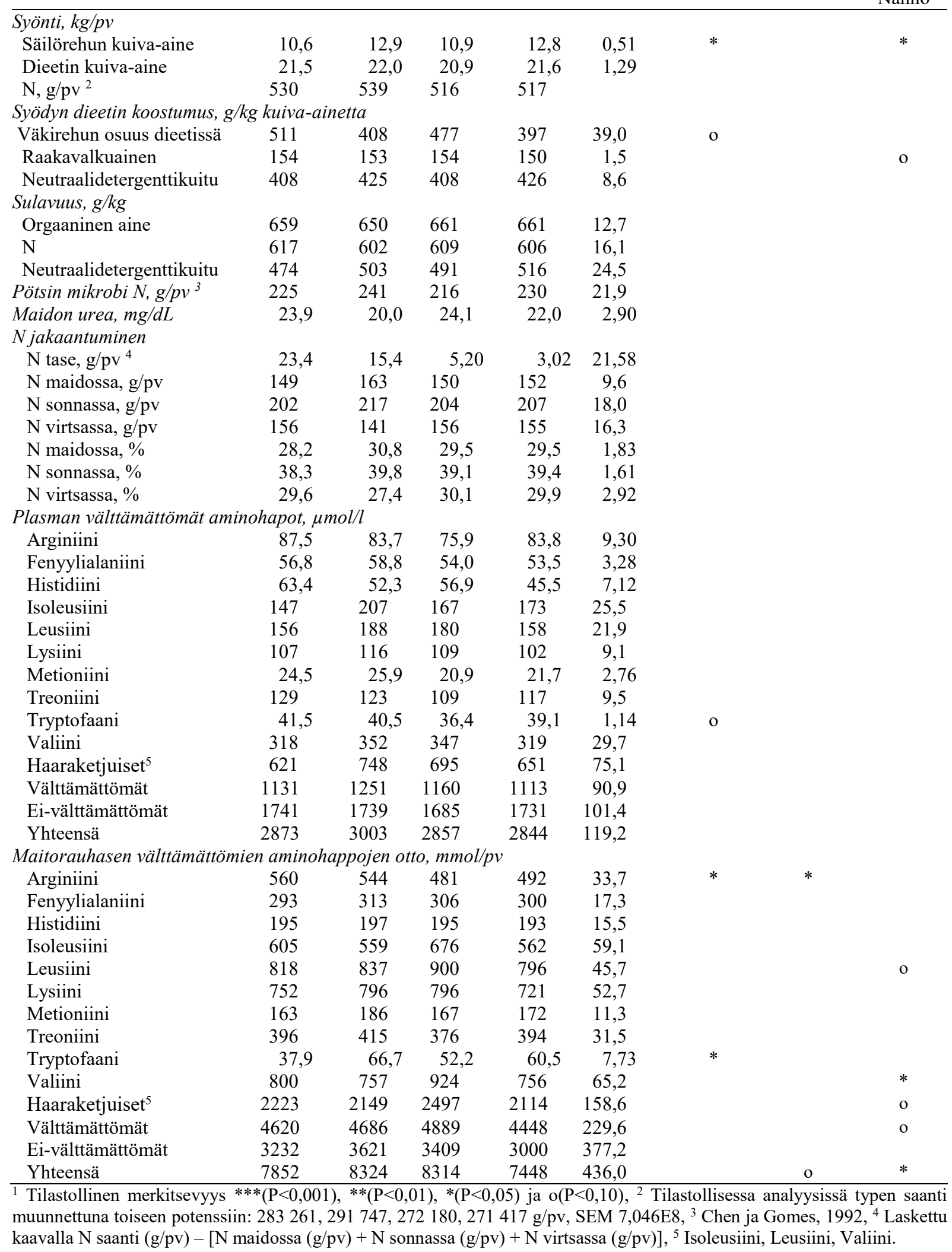


Mikrolevät lypsylehmien ruokinnassa: 2. Valkuaisen hyväksikäyttö

\section{JOHTOPÄÄTÖKSET}

Täydennysvalkuainen heikensi typen hyväksikäyttöä verrattuna kontrolliruokintaan ilman valkuaislisää. Säilörehun matalasta D-arvosta johtuen energian saanti saattoi rajoittaa molemmissa kokeissa valkuaisen hyväksikäyttöä. Useimmat Spirulinan valkuaisen hyväksikäyttöä kuvaavat muuttujat olivat hieman rypsirouhetta heikompia. Sen sijaan soijarouheen ja eri mikrolevälajien välillä ei ollut eroa valkuaisen hyväksikäytössä. Mikrolevien soijaa ja rypsiä pienempi histidiinipitoisuus ei todennäköisesti rajoittanut maidontuotantoa. Säilörehun ja edelleen kaikkien koeruokintojen raakavalkuaispitoisuus oli melko pieni, mistä johtuen rehutypen hyväksikäyttö maitovalkuaisen synteesiin oli kaikissa koeruokinnoissa korkealla tasolla, ollen keskimäärin $30 \%$.

\section{KIRJALLISUUS}

Allen, M.S. 2000. Effects of diet on short-term regulation of feed intake by lactating dairy cattle. Journal of Dairy Science 83:1598-1624.

Castillo, A.R., Kebreab, E., Beever, D.E. \& France, J. 2000. A review of efficiency of nitrogen utilisation in lactating dairy cows and its relationship with environmental pollution. Journal of Animal and Feed Sciences 9:132.

Chen, X.B. \& Gomes, M.J. 1992. Estimation of microbial protein supply to sheep and cattle based on urinary excretion of purine derivatives: An overview of technical details. International Feed Resources Unit, Occasional Publication. Rowett Research Institute, Aberdeen, Yhdistynyt Kuningaskunta.

Halmemies-Beauchet-Filleau, A., Lamminen, M., Kokkonen, T., Jaakkola, S. \& Vanhatalo A. 2016. Mikrolevät lypsylehmien ruokinnassa: 1. Maidontuotanto. Maataloustieteen Päivät 2016. www.smts.fi

Huhtanen, P. 2010. Märehtijöiden valkuaisarvojärjestelmä (OIV-PVT) uudistuu. Maataloustieteen päivät 2010. www.smts.fi

Huhtanen, P., Hetta, M. \& Swensson, C. 2011. Evaluation of canola meal as a protein supplement for dairy cows: A review and a meta-analysis. Canadian Journal of Animal Science 91:529-543.

Huhtanen, P., Nousiainen, J.I., Rinne, M., Kytölä, K. \& Khalili, H. 2008. Utilization and partition of dietary nitrogen in dairy cows fed grass silage-based diets. Journal of Dairy Science 91: 3589-3599.

Huhtanen, P. \& Shingfield, K.J. 2005. Grass silage: factors affecting efficiency of N utilisation in milk production. Teoksessa: Park, R.S. \& Stronge, M.D. (toim.). Silage production and utilisation. Proceedings of the XIVth International Silage Conference, a satellite workshop of the XXth International Grassland Congress, July 2005, Belfast, Northern Ireland. Wageningen Academic Publishers s. 35-50.

Huhtanen, P., Vanhatalo A. \& Varvikko, T. 2002. Effects of abomasal infusions of histidine, glucose, and leucine on milk production and plasma metabolites of dairy cows fed grass silage diets. Journal of Dairy Science 85:204-216.

Lamminen, M. 2014. Mikrolevien käyttö kotieläinten ravitsemuksessa. Maataloustieteen Päivät 2014. www.smts.fi

Luke 2015. Rehutaulukot ja ruokintasuositukset.

Verkkojulkaisu. https://portal.mtt.fi/portal/page/portal/Rehutaulukot Viitattu 3.12.2015.

Kaukovirta-Norja, A., Leinonen, A., Mokkila, M., Wessberg, N. \& Niemi, J. 2015. Tiekartta Suomen proteiiniomavaraisuuden parantamiseksi. VTT VISIONS 6. Verkkojulkaisu. http://www.vtt.fi/inf/pdf/visions/2015/V6.pdf Viitattu 10.12.2015.

Korhonen, M. 2003. Amino acid supply and metabolism in relation to lactational performance of dairy cows fed grass silage based diets. Väitöskirja. Helsingin yliopisto, Kotieläintieteen laitos. $45 \mathrm{~s}$.

Nousiainen, J., Kytölä, K., Khalili, H. \& Huhtanen, P. 2003. Ruokinnan mahdollisuudet parantaa typen hyväksikäyttöä maidontuotannossa. Teoksessa: Uusikämppä, J., Yli-Halla, M. \& Grék, K. (toim.) Lypsykarjataloudesta tulevan ympäristökuormituksen vähentäminen. Maa- ja elintarviketalous 25. MTT Jokioinen. s. 26-39.

Olmos Colmenero, J.J. \& Broderick, G.A. 2006. Effect of dietary crude protein concentration on milk production and nitrogen utilization in lactating dairy cows. Journal of Dairy Science 89:1704-1712.

Saarisalo, E., Jaakkola, S. \& Huhtanen, P. 1997. Valkuaistäydennyksen vaikutus maidontuotantokauden loppuvaiheessa. Kotieläintieteen päivät 1997.

Vanhatalo, A., Huhtanen, P., Toivonen, V. \& Varvikko, T. 1999. Response of dairy cows fed grass silage diets to abomasal infusions of histidine alone or in combinations with methionine and lysine. Journal of Dairy Science 82:2674-2685.

Ylinen, V. 2015. Mikrolevä lypsylehmien valkuaisrehuna - vaikutus syöntiin, aineenvaihduntaan ja maidontuotantoon. Maisterintutkielma. Helsingin yliopisto, Maataloustieteiden laitos. 63s. 